\title{
Genotype analysis of partial growth hormone gene (GH891 | MspI) in Pesisir cattle and Simmental-Pesisir crossbred cattle
}

\author{
T. Hartatik ${ }^{1}$,* , D. E. Putra ${ }^{2}$, S. D. Volkandari ${ }^{3}$, T. Kanazawa ${ }^{4}$ and Sumadi ${ }^{1}$ \\ ${ }^{1}$ Laboratory of Animal Genetics and Breeding, Faculty of Animal Science, Universitas Gadjah Mada, \\ Jl Fauna 3 Bulaksumur, Sleman, Yogyakarta 55281 - Indonesia \\ ${ }^{2}$ Laboratory of Animal Genetics and Breeding, Faculty of Animal Science, Andalas University, \\ Jl. Dr. M. Hatta, Kampus Unand Limau Manis, Padang 25163 - Indonesia \\ ${ }^{3}$ Research Center for Biotechnology, Indonesian Institute of Sciences (LIPI), \\ Jln Raya Bogor km 46, Cibinong, Bogor, West Java 16911 - Indonesia \\ ${ }^{4}$ Department of Animal Cell Science and Engineering, School of Agriculture, Ibaraki University, \\ Ami, Ibaraki 300-0393 - Japan \\ *CorrespondingE-mail : tety@ugm.ac.id
}

Received August 31, 2017; Accepted January 09, 2018

\begin{abstract}
ABSTRAK
Gen Growth Hormone (GH) merupakan sebuah gen yang mengontrol sintesis hormon pertumbuhan dan berperan dalam metabolisme tubuh. Identifikasi polimorfisme suatu gen penting dilakukan untuk memperoleh informasi awal dalam mengetahui penanda genetik yang berhubungan dengan sifat-sifat ekonomis yang diinginkan. Pemetaan genetik sangat penting dalam proses seleksi. Sapi Pesisir adalah salah satu sapi lokal Indonesia yang ditemukan di Sumatera Barat dan sangat adatif terhadap lingkungan setempat. Penelitian ini bertujuan untuk mengidentifikasi genotip berdasarkan sebagian gen Growth Hormone (GH891|MspI) pada sapi Pesisir dan sapi Persilangan Simmental-Pesisir (SimPes) dan hubungannya dengan sifat pertumbuhan (ukuran tubuh dan berat badan). Sebanyak 30 sampel darah sapi yang terdiri dari 15 Sapi Pesisir dan 15 Sapi SimPes digunakan dalam penelitian ini. Ukuran tubuh dan berat badan sapi diukur pada umur 12-18 bulan. Metode analisis yang digunakan adalah Polymerase Chain Reaction-Restriction Fragment Length Polymorphism (PCR-RFLP). Hasil menunjukkan bahwa terdapat tiga (3) variasi genotip (MspI-/-, MspI+/-, MspI+/+) dengan frekuensi alel sebesar 53,3\% untuk alel MspI- dan 46,7\% untuk MspI+. Tidak ditemukan hubungan yang signifikan antara ukuran tubuh dan bobot badan kedua bangsa sapi tersebut berdasarkan ketiga genotip gen GH (GH891|MspI). Kesimpulan, terdapat tiga genotip gen GH pada populasi sapi Pesisir dan SimPes dan tidak berpengaruh signifikan terhadap performans pertumbuhan sapi.
\end{abstract}

Kata Kunci: genotip, enzim MspI, gen Pertumbuhan, sifat pertumbuhan, sapi Pesisir, sapi SimPes

\section{ABSTRACT}

Growth hormone gene that controls metabolism and body size of animals and polymorphism of the gene is known related to performance of livestock. Identification of gene polymorphisms was important to get early information to determine genetic markers associated with economically desirable traits. Genetic mapping is one of important characterizations in the selection process. Pesisir cattle is one of local cattle in Indonesia that are reared in West Sumatera and have become adaptive to local environment. The present study aimed to identify the genotype of Growth Hormone gene (GH891 |MspI) of the Pesisir cattle and crossbred Simmental-Pesisir cattle (designated as SimPes) and relationship between growth performance (body weight and body size). The present study was 
conducted to 30 blood samples consisted of 15 Pesisir cattle and 15 SimPes cattle. Body weight and body size were measured at 12-18 months of age. The Polymerase Chain Reaction-Restriction Fragment Length Polymorphism (PCR-RFLP) method was used in this research. The results showed that there exist three variant genotypes (MspI-/-, Msp I+/-, Msp I+/+) and that allele frequencies of $M s p \mathrm{I}-$ and $M s p \mathrm{I}+$ were $53.3 \%$ and $46.7 \%$, respectively. Non-significant effect has found between GH's genotype and growth traits (Body measurement and body weight) in both of breed cattle. In conclusion, three variant genotypes (GH891|MspI) in Pesisir and SimPes (Simmental x Pesisir) cattle population were found and no significant effect on growth trait performance.

Keywords : genotype, MspI enzyme, growth hormone gene, growth trait, Pesisir cattle, SimPes cattle

\section{INTRODUCTION}

Pesisir cattle is one of the local cattle in Indonesia that are reared in West Sumatera and have been well adapted in the area. Pesisir cattle has an ability to convert low quality feed for meat production (Hendri, 2013), which the ability is considered to be one of desirable characters. Recently, crossbred cattle has become very popular among areal farmers because growth rates of crossbreds are higher than indigenous local cattle. Simmental breed is chosen for crossing with local cattle, since Simmental cattle has more muscular body, grow faster and adaptive to local climate and feeding.

Growth traits of livestock animals, including body weight, body size, and carcass weight, are regulated by multiple genes. Growth hormone (GH) gene is one of those genes: It encodes growth hormone, which has important roles in control of the body metabolism (Moravčiková et al., 2012). Growth Hormone directly or indirectly plays a role in tissue growth and fat metabolism, so that it has an important role in growth traits, reproduction and lactation in cattle (Tatsuda et al., 2008). The growth hormone is a single-chain polypeptide consisting of 191 amino acids that is synthesized and secreted by the anterior pituitary gland (Nicoll et al., 1986; Moravčiková et al., 2012). Growth hormone gene is located in chromosome 19 in bovine (Hediger et al., 1990). Growth hormone gene contains 5 exons and 4 introns (Woychik et al., 1982 cit. Yardibi et al., 2009). In earlier study, Ries et al. (2001) reported that polymorphism in GH gene is found at position 127 (substitution) in exon 5. Nucleotide transversion of Guanine to Adenine changed (substitution) of amino acid (Leucine to Valine) that is recognized by $A l u \mathrm{I}$ Restriction enzyme (Gordon et al., 1983). This single nucleotide polymorphism (SNP) resulted in two variant alleles: L and V. Allele $\mathrm{L}$ is more dominant than allele $\mathrm{V}$ in Holstein cattle (Mohammadabadi et al., 2010; Hadi et al., 2015), Zavot cattle/native Turkish cattle breeds (Akçay et al., 2015), Turkish cattle (Özkan ünal et al., 2015), Madura cattle (Hartatik et al., 2013) and Pesisir cattle (Putra et al., 2016). Jakaria and Noor (2011) reported that monomorphic $\mathrm{L}$ of $\mathrm{GH}$ gene has been found in Bali cattle from Bali Islands. The other Indonesian local beef cattle which have monomorphic allele $\mathrm{L}$ has been found in Madura cattle (Hartatik et al., 2013).

Single Nucleotide Polymorphism at 2141 of GH gene associated with average live body weight in Alentejana, Marinhoa, and Preta breed (Portuguese breeds) (Reis et al., 2001). The other SNPs have been found in GH gene that located in intron 3. The SNP is recognition site of $M s p \mathrm{I}$ restriction enzyme. The presence of mutations in intron 3 is also found in some cattle such as Sumba Ongole (SO) cattle (Anwar et al., 2015), Aceh cattle (Putra et al., 2013), Kenana Butana cattle (Musa et al., 2013). Two alleles are observed as a result i.e. the first allele, GH-MspIcontains an insertion of $\mathrm{T}$ at the +837 position, and the second allele has a C-G transition at the +837 position (Zhang et al., 1993).

Growth traits of cattle are great concern during selection. The association of the $\mathrm{GH}$ gene with growth traits is important for investigation because it could be candidate gene for selection program based on marker (Marker Assisted Selection) and as a tool for breeding. Evaluation of genetic polymorphisms may be more easily evaluated in Bos indicus vs. Bos taurus crossbred cattle. Growth hormone $M s p \mathrm{I}$ (GH891|MspI) at intron 4 (1182 to 2072) in the GH gene has been determined to evaluate the association of DNA polymorphisms to growth and carcass characteristics in a larger population of Brahman steers (Beauchemin et al., 2006). The aim of this study was to determine of GH891's genotype in Pesisir cattle and crossed breed (Simmental $\mathrm{x}$ 
Pesisir) and their association with body size.

\section{MATERIALS AND METHODS}

\section{Collection of Blood Samples and Trait Data}

Thirty samples of local beef cattle ( 15 heads of Pesisir cattle and 15 heads of SimPes (Simmental x Pesisir) cattle) were taken from South Pesisir Regency at West Sumatera. Three milliliters of blood samples were collected from jugular vein. Blood samples were stored at $4^{\circ} \mathrm{C}$ until DNA isolation. Molecular analysis had been conducted at Animal Breeding and Genetics of Faculty of Animal Science, UGM. Quantitative data in this research were consisted of body measurements (body length (BL), height of shoulder (HS), height of hip (HH), Heart Girth (HG) and body weight (BW)). Body length performed by measuring the distance from the neck of the shoulder/scapula to the tip of the pelvis (procesus spinus) is expressed in $\mathrm{cm}$, height shoulder performed by measuring the perpendicular distance from the ground to the peak of the shoulder behind the hump, expressed in $\mathrm{cm}$, height hip is done by measuring the perpendicular distance from the ground to the top of the hip, expressed in $\mathrm{cm}$, heart girth performed by looping the tape measure on the back of the shoulders expressed by $\mathrm{cm}$ and body weight is the weight obtained during the cattle kept and alive and weighed expressed in kilo grams.

\section{DNA Isolation}

DNA was isolated according to the procedure conducted by Putra et al. (2016). Two hundreds microliters of blood sample in $1.5 \mathrm{~mL}$ microtubes were added with $800 \mu \mathrm{L}$ of buffer $\mathrm{A}$ $((0.32 \mathrm{M}$ Sucrose (Himedia, India); $10 \mathrm{mM}$ TrisHCL $\mathrm{pH} \quad 7.5 ; 5 \mathrm{mM} \quad \mathrm{MgCl}_{2}$ (Merck, Germany), $\quad 1 \% \quad$ Triton $\mathrm{X}-100 \quad$ (applichem); DDW)), and it was mixed carefully. Samples were centrifuged at $10,000 \mathrm{rpm}$ for 5 minutes. The supernatant was discarded and added with $300 \mu \mathrm{L}$ of buffer A. The pellet was resuspended with buffer A. Then, the samples were centrifuged at $10,000 \mathrm{rpm}$ for 5 minutes. The pellet was washed until pink or pale color. Two hundred and seventy microliters of buffer $B$ solution $((5 \mathrm{M} \mathrm{NaCl}$ (Merck, Germany); 0.2 M EDTA pH 8.0 (Merck, Germany); $10 \mathrm{mM}$ TrisHCL pH $8.0\left(1^{\text {st }}\right.$ Base, Singapore); DDW)) and $30 \mu \mathrm{L}$ of buffer $\mathrm{C}$ solution $((2 \mathrm{mg} / \mathrm{ml}$ proteinase $\mathrm{K}$ (Geneaid, PT Genetika Science Indonesia); 10xSDS; DDW)) were added to $1.5 \mathrm{~mL}$ microtube with pellet inside. Samples were incubated overnight at $50^{\circ} \mathrm{C}$. The pellet will lysis and mix with buffer. Seventy one microliters $5 \mathrm{M}$ of $\mathrm{NaCl}$ (Merck, Germany) was added to microtube and shaked vigorously for 15 seconds. The sample was centrifuged at 10,000 rpm for 10 minutes. Supernatant of samples (300 $\mu \mathrm{L})$ were taken carefully using blue tip. Ethanol $96 \%$ was used for precipitation of DNA and 70\% for washing it. After that, the sample was centrifuged at $12,000 \mathrm{rpm}$ for 10 minutes. DNA pellet were dried then added with $100 \mu \mathrm{L}$ TE buffer to dissolve DNA. The isolates were run at 1 $\%$ agarose $\left(1^{\text {st }}\right.$ Base, Singapore) for checking of genomic DNA.

\section{Polymerase Chain Reaction (PCR)}

The amplification of specific DNA fragment (Growth Hormone Gene 891bp) used Polymerase Chain Reaction (PCR) method that located at intron 4 (1182 to 2072, GenBank Accession Number M57764) in the GH gene. Pair of GH891 primers in the research was based on Beauchemin et al. (2006), GH-forward: 5' ATC CAC ACC CCC TCC ACA CAG T $3^{\prime}$ and GH-reverse: 5' CAT TTT CCA CCC TCC CCT ACA G 3'. Total volume of PCR reaction was $30 \mu \mathrm{L}$ consisted of $15 \mu \mathrm{L}$ PCR Kit KAPA (Kappa BioSystem, USA), forward and reverse primers $1.5 \mu \mathrm{L}$ each $(10$ $\mathrm{pmol} / \mu \mathrm{L}), 11.25 \mu \mathrm{L}$ double distillated water (DDW), and $0.75 \mu \mathrm{L}$ DNA template (approximately 50-100 ng). The PCR analysis was performed by pre-denaturation program at $97^{\circ} \mathrm{C}$ for 1 minute 30 seconds, denaturation at $94^{\circ} \mathrm{C}$ for 1 minute, annealing at $62^{\circ} \mathrm{C}$ for 1 minute, extension at $72^{\circ} \mathrm{C}$ for 1 minute, with 34 cycles. Post extension at $72^{\circ} \mathrm{C}$ for 10 minutes (Zhang et al., 1993). PCR product was run on $1 \%$ agarose gel $\left(1^{\text {st }}\right.$ Base, Singapore $)$ and visualized under UV light using UV transilluminator.

\section{Polymerase Chain Reaction-Restriction Fragment Length Polymorphism (PCR-RLFP) Polymerase Chain Reaction-Restriction} Fragment Length Polymorphism (PCR-RLFP) method was employed for genotype analysis of GH891 using MspI restriction enzyme, according to the procedure of Putra et al. (2013) and Putra et al. (2016). Briefly, $10 \mu \mathrm{L}$ of PCR products were digested using $3 \mathrm{U}$ of $M s p \mathrm{I}$ enzyme (Fermentas, Life Science) and incubated for 5 hours at $37^{\circ} \mathrm{C}$. PCR-RFLP products were run on $2 \%$ agarose gel 
( $1^{\text {st }}$ Base, Singapore), stained with Ethidium bromide and visualized by UV-light illumination.

\section{DNA Sequencing}

Since the PCR-RFLP with MspI showed multiple bands and seemed not to be specific for $M s p \mathrm{I}$ restriction mapping (Figure 1A), the samples were sequenced. The PCR products of 30 $\mu 1$ and single primer forward were send to PT Genetika Science for sequencing. Sequencing process used BigDye ${ }^{\circledR}$ Terminator v3.1 Cycle Sequencing Kit with the machine ABI PRISM 3730xl Genetic Analyzer develop by Applied Biosystems, USA.

\section{Statistical Analysis}

Frequencies of genotype and allele were calculated with the mathematical model as follow: $\mathrm{p}^{2}+2 \mathrm{pq}+\mathrm{q}^{2}=1$

Where:

$$
\begin{aligned}
& \mathrm{p}^{2}: \text { frequency of } M s p \mathrm{I}-/- \\
& 2 \mathrm{pq}: \text { frequency of } M s p \mathrm{I}+/- \\
& \mathrm{q}^{2}: \text { frequency of } M s p \mathrm{I}+/+
\end{aligned}
$$

Hardy-Weinberg Equilibrium was calculated according to Warwick et al. (1990).

$$
x^{2}=\sum \frac{(0-E)^{2}}{E}
$$

Where:

$x^{2}$ : Pearson's cumulative test statistic, which asymptotically approaches a $\chi^{2}$ distribution

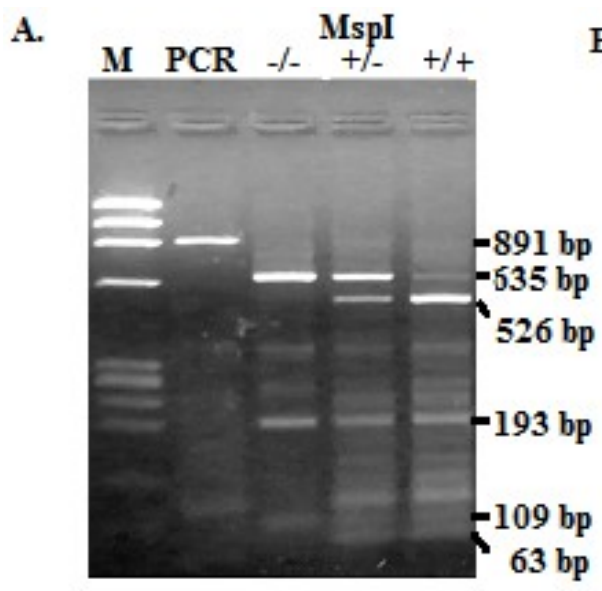

E : the expected (theoretical) frequency

$\mathrm{O} \quad$ : the number of observations

Relationship of phenotype data (growth trait parameters) with genotype was analyzed using SPSS version 17.0 software.

\section{RESULTS AND DISCUSSIONS}

Growth hormone gene has been explored on both beef cattle (Tambasco et al., 2003; Pereirra et al., 2005; Mu'in, 2008) and dairy cattle (Biswas et al., 2003; Aruna Pal et al., 2004) associating with growth traits performance. In the present study, growth hormone gene has been amplified using PCR technique with $891 \mathrm{bp}$ of length starting at 1182 to 2052 . Determination of genotype and detection of polymorphism used $M s p I$ restriction enzyme. The digested product showed that three variants of genotype i.e. $M s p \mathrm{I}(+/+), M s p \mathrm{I}(+/-)$ and $M s p \mathrm{I}(-/-)$. Genotype $M s p \mathrm{I}(+/+)$ product exhibited four fragments of 526; 193; 109 and 63 bp. For MspI (-/-) genotype was generated of three fragments i.e. $635 ; 193$ and $63 \mathrm{bp}$ while heterozygote (MspI (+/-) produced five fragments $(635 ; 526 ; 193 ; 109$ and $63 \mathrm{bp})$ (Figure 1A). Illustration for specific fragments of GH891 $\mid$ MspI is shown in Figure 1B.

Base sequence of GH891 | MspI, as shown in Figure 2, denotes substitution of nucleotide (Thymine to Cytosine). Those substitutions were recognized by $M s p \mathrm{I}$ restriction enzyme $\left(\mathrm{CC}^{\wedge} \mathrm{GG}\right)$ and produced three genotypes (MspI-/-, MspI-/+, $M s p \mathrm{I}+/+)$ in Pesisir and SimPes cattle. This is the evidence of genotype pattern in Figure 1.

Figure 1. PCR-RFLP of GH891 $\mid$ MspI of Pesisir and SimPes cattle (A) and Illustration for specific fragments of GH891 |MspI (B). (M=Marker Ø 174 DNA/BsuRI \& HaeIII) 
A.

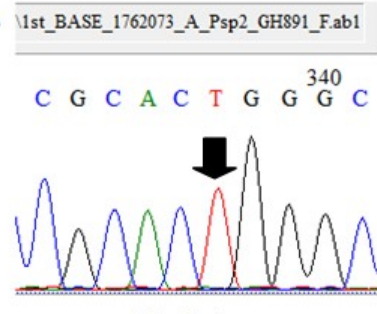

MspI-/-
B.
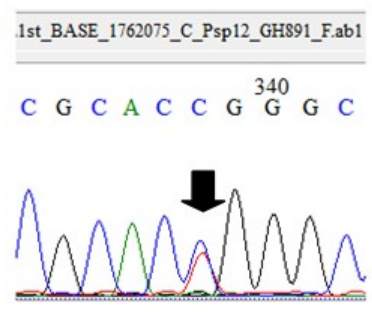

MspI+/-
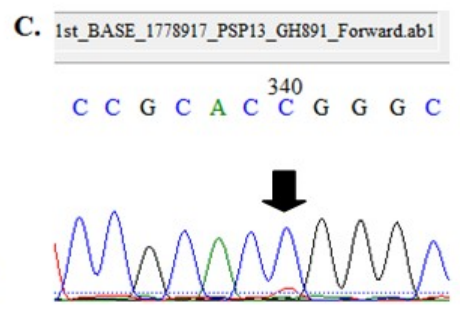

MspI $+/+$

Figure 2. Base sequence analyses of $M s p \mathrm{I}-$ recognision site of genotypes $M s p \mathrm{I}-/-, M s p \mathrm{I}+/-$ and $M s p \mathrm{I}+/+$ among GH891 PCR products.

Table 1. Frequency of Genotypes and Allele GH891 | MspI on Pesisir and SimPes Cattle

\begin{tabular}{|c|c|c|c|c|c|c|}
\hline \multirow{2}{*}{ Breed } & \multirow{2}{*}{$\mathrm{N}$} & \multicolumn{3}{|c|}{ Genotypes Frequency } & \multicolumn{2}{|c|}{ Alleles Frequency } \\
\hline & & MspI-/- & $M s p \mathrm{I}+/-$ & MspI+/+ & MspI- & Msp $\mathrm{I}^{+}$ \\
\hline Pesisir & 15 & $0.333(5)$ & $0.400(6)$ & $0.267(4)$ & 0.533 & 0.467 \\
\hline SimPes & 15 & $0.133(2)$ & $0.800(12)$ & $0.067(1)$ & 0.533 & 0.467 \\
\hline
\end{tabular}

SimPes: Simmental-Pesisir

Table 2. $\chi^{2}$ test of GH891 |MspI Genotype of Pesisir and SimPes cattle Populations

\begin{tabular}{|c|c|c|c|c|c|c|c|}
\hline \multirow{2}{*}{$\begin{array}{c}\text { Cattle } \\
\text { Population }\end{array}$} & \multirow[b]{2}{*}{ Number } & \multicolumn{3}{|c|}{ Genotype } & \multicolumn{2}{|c|}{ Allele Frequency } & \multirow{2}{*}{$X^{2}$} \\
\hline & & Msp $\mathrm{I}-/-$ & Msp $\mathrm{I}+/-$ & $M s p \mathrm{I}+/+$ & MspI- & Msp I+ & \\
\hline \multirow[t]{2}{*}{ Pesisir } & Observed & 5 & 6 & 4 & 0.533 & 0.467 & 0.58 \\
\hline & Expected & 4.26 & 7.47 & 3.27 & & & \\
\hline \multirow[t]{2}{*}{ SimPes } & Observed & 2 & 12 & 1 & 0.533 & 0.467 & 5.53 \\
\hline & Expected & 4.26 & 7.47 & 3.27 & & & \\
\hline
\end{tabular}

$\mathrm{X}_{0.05 ; 2}^{2}=5.99$; GH: Growth Hormone

Frequencies of genotype and allele are presented at Table 1.

The result of the present study showed that the $M s p \mathrm{I}$-allele was more frequent than the $M s p \mathrm{I}+$ ( 0.533 vs 0.467 ) on both of cattle breed. Genotype frequency of $M s p \mathrm{I}+/-$ was higher than genotype $M s p \mathrm{I}-/-$ and $M s p \mathrm{I}+/+$ of each breed of cattle (Table 1). Polymorphic GH891|MspI have been found in populations of Pesisir and SimPes cattle. Variants of alleles in $\mathrm{GH}$ locus did not change genetic equilibrium in that population (Table 2). Previous study, Sodhi et al. (2007) reported that frequency of MspI- in Indian cattle breeds was higher than $M s p \mathrm{I}+$ in taurine breeds (Bos taurus) from northern Eroupe, Mediteranean countries, and America. Frequencies of $M s p \mathrm{I}$-alleles were $0.94 ; 0.90 ; 0.88 ; 0.90$ and 0.80 for Sahiwal, Tharparkar, Gir, Ongole and Hariana, respectively. In eastern Africa, Musa et al. (2013), found that MspI- of Butana and Kenana cattle breeds were lower than Indian cattle breeds.

In the present study, the chi-square test revealed that the allele distribution in this locus was still at Hardy-Weinberg equilibrium for the SimPes cattle as well as in Pesisir cattle. The results showed chi-square test for SimPes cattle 
Table 3. Averages Body Weight and Body Size of Pesisir and SimPes Cattle Based on Genotype GH891 $\mid$ MspI at the Age $12-18$ Months for Bulls and Cows

\begin{tabular}{|c|c|c|c|c|c|c|}
\hline \multirow{3}{*}{ Variable } & \multicolumn{6}{|c|}{ Breed (Genotype) } \\
\hline & \multicolumn{3}{|c|}{ PSP } & \multicolumn{3}{|c|}{ SP } \\
\hline & $(M s p \mathrm{I}-/-)$ & $(M s p I+/-)$ & $(M s p \mathrm{I}+/+)$ & $(M s p I-/-)$ & $(M s p \mathrm{I}+/-)$ & $\begin{array}{c}(M s p \mathrm{I}+/ \\
+)\end{array}$ \\
\hline $\mathrm{N}$ & 5 & 6 & 4 & 2 & 12 & 1 \\
\hline BW (kg) & $130.00 \pm 28.22$ & $131.08 \pm 25.00$ & $141.38 \pm 30.05$ & $159.00 \pm 52.33$ & $182.79 \pm 23.84$ & 135.00 \\
\hline $\mathrm{BL}(\mathrm{cm})$ & $83.60 \pm 6.43$ & $87.17 \pm 9.56$ & $91.75 \pm 9.98$ & $90.50 \pm 9.19$ & $98.17 \pm 4.88$ & 89.00 \\
\hline $\mathrm{HS}(\mathrm{cm})$ & $94.80 \pm 8.84$ & $91.17 \pm 8.89$ & $101.25 \pm 2.50$ & $96.00 \pm 4.24$ & $99.83 \pm 4.57$ & 93.00 \\
\hline $\mathrm{HH}(\mathrm{cm})$ & $101.40 \pm 6.73$ & $97.50 \pm 8.22$ & $106.75 \pm 3.30$ & $105.50 \pm 9.19$ & $106.17 \pm 5.87$ & 97.00 \\
\hline $\mathrm{HG}(\mathrm{cm})$ & $116.60 \pm 12.86$ & $115.33 \pm 7.63$ & $118.25 \pm 9.18$ & $131.00 \pm 14.14$ & $131.67 \pm 6.31$ & 120.00 \\
\hline
\end{tabular}

$\mathrm{PSP}=$ Pesisir cattle, $\mathrm{SP}=$ Simmental $\times$ Pesisir cattle $\mathrm{BW}=$ body weight, $\mathrm{BL}=$ body length, $\mathrm{HS}=$ height shoulder, $\mathrm{HH}=$ hip height, $\mathrm{HG}=$ heart girth

$\left(X^{2}=5.53\right)$ and Pesisir cattle $\left(X^{2}=0.58\right)$ which lower than the standard tabel of $\mathrm{X}^{2}=5.99$ (Table 2).

Genotypes of GH gene showed no significant differences on growth trait performance (Table 3) in both of cattle breed (Pesisir and SimPes cattle). Due to the limited number of sample ( $\mathrm{N}=15$ each group), no statistical analysis was performed. Similarly Beauchemin et al. (2006) has reported that effects of $M s p$ I polymorphism were not found in Brahman cattle and Nellore cattle population (Cardoso et al., 2014). On the contrary, Unanian et al. (2000) reported that MspI polymorphism effects on the growth traits in Nellore cattle population and describes a significant effect on the average daily gain (ADG) from weaning at 15 months with DD genotype (equivalent with $M s p \mathrm{I}-/-)$ and weight at first estrus and first calving in heifers in Holstein cattle (Arango et al., 2014). For the other SNP of GH in cattle, Reis et al. (2001) reported that genotype LV of Portuguese cattle breeds have weight live higher than LL and VV in mature weight.

Validation of genetic factor is important for genetic improvement of local cattle population in Indonesia based on molecular analysis. It could be used for early entry in future breeding program.

\section{CONCLUSIONS}

Three variant genotypes of (GH891 $\mid$ MspI) in Pesisir and SimPes cattle (Simmental x Pesisir) were found and these genotype variations had no apparent effects on growth trait performances.

\section{ACKNOWLEDGMENTS}

Authors would like to thank for Publisher and Publication Board Universitas Gadjah Mada provided us financial support for improving the quality of manuscript. DNA samples in this study was part of DNA samples collected by Dino Eka Putra.

\section{REFERENCES}

Akçay, A., B. Akyüz and D. Bayram. 2015. Determination of the AluI polymorphism effect of bovine growth hormone gene on carcass traits in Zavot cattle with analysis of covariance. Turk. J. Vet. Anim. Sci. 39:1622.

Anwar, S., P.P. Agung, A.S. Wulandari, A. Sudiro, S. Said and B. Tappa. 2015. Detection of growth hormone (GH-MspI) gene polymorphism in Sumba Ongole (SO) cattle. Proc Semnas Masy Biodiv Indon. June 13, 2015. P. $398-403$

Arango, J., Z.J. Echeverri and H.A. Lopez. 2014. Association of the bovine growth hormone gene with Hosltein cattle reproductive parameters. Rev. MVZ. Cordoba 19(3):4249-4258.

Beauchemin, V.R., M.G. Thomas, D.E. Franke and G.A. Silver. 2006. Evaluation of DNA 
polymorphisms involving growth hormone relative to growth and carcass characteristics in Brahman steers. Genet. Mol. Res. 5:438447.

Biswas, T. K., T.K. Bhattacharya, A.D. Narayan, S. Badola, P. Kumar and A. Sharma. 2003. Growth hormone gene polymorphism and its effect on birth weight in cattle and buffalo. Asian-Aust. J. Anim. Sci. 16:494-497.

Cardoso, D.F., F.R.P. de Souza, G.M.F. de Camargo, P.D. da Silva Fonseca, C.U. Braz, A.A. Boligon, M.E.Z. Mercadante, L.G. de Albuquerque, and H.Tonhati. 2014. Polymorphism analysis in genes of the somatotropic axis in Nellore cattle selected for growth. Gene. 545:215-219.

Gordon, D.F., D.P. Quick, C.R. Erwin, J.E. Donelson and R.A. Maurer. 1983. Nucleotide sequence of the bovine growth hormone chromosomal gene. Mol. Cell Endocrinol. 33:81-95.

Hadi, Z., H. Atashi, M. Dadpasand, A. Derakhshandeh and M.M. Ghahramani Seno. 2015. The relationship between growth hormone polymorphism and growth hormone receptor genes with milk yield and reproductive performance in Holstein dairy cows. Iran. J. Vet. Res. 16(3):244-248.

Hartatik, T., S.D. Volkandari, M.R.P. Rachman and Sumadi. 2013. Polymorphism lue/val of growth hormone gene identified from limousine cross local cattle in Indonesia. Procedia Environ. Sci. 17:105-108.

Hediger, R., S.E. Johnson, W. Barendse, R.D. Drinkwater, S.S. Moore and J. Hetzel. 1990. Assignment of the growth hormone gene locus to 19q26-qter in cattle and to 11q25qter in sheep by in situ hybridization. Genomics 8:171-174.

Hendri, Y. 2013. Development of Pesisir cattle as a local breed of West Sumatera. J. Litbang. Pert. 32(1):39-45.

Jakaria and R.R. Noor. 2011. Analysis on AluIGrowth Hormone (GHAluI) gene in Bali cattle. J. Indonesian Trop. Agric. 36(2):7782.

Özkan ünal, E., E.S. Kepenek, H. Dinç, F. Özer, G. Sőnmez, I.Z. Toğan, and M.I. Soysal. 2015. Growth hormone (GH), Prolactin (PRL) and diacylglyserol acyltranferase (DGAT1) gene polymorphism in Turkish native cattle breeds. Turk. J. Zool. 39:1-15.

Mohammadabadi, M. R., A. Torabi, M. Tahmourespoor, A. Baghizadeh, A.
Esmailizadeh Koshkoleh and A. Mohammad. 2010. Analysis of bovine growth hormone gene polymorphism of local and Holstein cattle breeds in Kerman province of Iran using polymerase chain reaction restriction fragment length polymorphism (PCR-RFLP). Afr. J. Biotechnol. 9(41):6848-6852.

Moravčiková, N., A. Trakovická and E. Hazuchová. 2012. The association of bovine growth hormone gene polymorphism with milk performance traits in Slovak Spotted Cows. Sci. Pap: Anim. Sci. Biotechnol. 45(1):206-210.

Mu'in, M.A. 2008. Genetic polymorphism of growth hormone and insulin-like growth factor-1 and association with pre-weaning of beef cattle in Indonesia. Dissertation. Postgraduate Program, Faculty of Animal Science, Universitas Gadjah Mada. Yogyakarta.

Musa, L.M.A., M. Reissmann, I.A. Ishag, S.A. Rahamtalla, G. Brockmann, and J.K. Peters. 2013. Characterization of the growth hormone $(\mathrm{GH})$ in Sudanese Kenana and Butana cattle breeds. J. Anim. Prod. Adv. 3(2):28-34.

Nicoll, C.S., G.L. Mayer and S.M. Russell. 1986. Structural features of prolactin and growth hormones that can be related to their biological properties. Endocrinol. Rev. 7:169-203.

Pal, A., A. K. Chakravarty, T. K. Bhattacharya, B.K. Joshi and A. Sharma. 2004. Detection of polymorphism of growth hormone gene for the analysis of relationship between allele type and growth traits in Karan Fries cattle. Asian-Aust. J. Anim. Sci. 17(10):1334-1337.

Pereira, A. P., M.M. de Alencar, H.N. de Olivera and L.C.de A. Regitano. 2005. Association of GH and IGF-1 polymorphisms with growth traits in a synthetic beef cattle breed. Genet. Mol. Biol. 28:230-236.

Putra, W.P.B., T. Hartatik and Sumadi. 2013. Growth hormone gene genotyping by MspI restriction enzyme and PCR-RFLP methods in Aceh cattle breed at Indrapuri district of Aceh province. J. Indonesian Trop. Anim. Agric. 38 (4):207-211.

Putra, D.E., Sumadi, T. Kanazawa and T. Hartatik. 2016. Identification of growth hormone gene polymorphism for beef cattle in Pesisir Selatan District, West Sumatra, Indonesia. 
Biodiversitas 17(2):711-715.

Reis, C., D. Navas, M. Pereira and A. Cravador. 2001. Growth hormone AluI polymorphism analysis in eight Portuguese bovine breeds. Arch. Zootec. 50:4-48.

Sodhi, M., M. Mukesh, B. Prakash, B.P.Mishra, R.C.Sobti, K.P. Singh, S. Singh and S.P.S. Ahlawat. 2007. MspI allelic pattern of bovine growth hormone gene in Indian Zebu cattle (Bos indicus) breeds. Biochem. Genet. 45:145-153.

Tambasco, D.D., C.C.P. Paz, M. TambascoStudart, A.P. Pereira, M.M. Alencar, A.R. Freitas, L.L. Coutinho, I.U. Packer and L.C.A. Regitano. 2003. Candidate genes for growth traits in beef cattle crosses Bos taurus x Bos indicus. J. Anim. Breed. Genet. 120:51-54.

Tatsuda, K., A. Oka, E. Iwamoto, Y. Kuroda, H. Takeshita, H. Kataoka and S. Kouno. 2008. Relationship of the bovine growth hormone gene to carcass traits in Japanese Black
Cattle. J. Anim. Breed. Genet. 125:45-49.

Unanian, M.M., C.C. Barreto, A.R.D. Freitas, C.M.T. Cordeiro, and L.A. Josahkian. 2000. Associations between growth polymorphism and weight traits in Nellore bovines. Rev. Bras. Zootec. 29:1380-1386.

Warwick, E.J and J.E. Legates. 1990. Breeding and Improvement of Farm Animals. 8th ed. Mc. Graw-Hill Publishing Company. Singapore.

Yardibi, H., G.T. Hosturk, I. Paya, F. Kaygisiz, G. Ciftioglu, A. Mengi, and K.Oztabak. 2009. Association of growth hormone gene polymorphisms with milk production traits in South Anatolian and East Anatolian Red cattle. J. Anim. Vet. Adv. 8(5):1040-1044.

Zhang, H.M., D.R. Brown, S.K. Denise and R.L. Ax. 1993. Polymerase chain reactionrestriction fragment length polymorphism analysis of the bovine somatotropin gene. J. Anim. Genet. 71:2276-2282. 